\title{
Arthropod Diversity and Functional Importance in Old-Growth Forests of North America
}

\author{
Timothy Schowalter
}

Entomology Department, Louisiana State University Agricultural Center, Baton Rouge, LA 70803, USA; tschowalter@agcenter.lsu.edu; Tel.: +1-225-578-1827

Academic Editors: Jarmo K. Holopainen and Timothy A. Martin

Received: 26 January 2017; Accepted: 23 March 2017; Published: 25 March 2017

\begin{abstract}
Old-growth forests have become rare in North America but provide habitat for unique assemblages of species that often are rare in younger forests. Insects and related arthropods reach their highest diversity in old-growth forests because of their stable moderate temperature and relative humidity and the rich variety of resources represented by high plant species richness and structural complexity. Old-growth arthropod assemblages typically are distinct from those in younger, managed forests. Major subcommunities include the arboreal community that is composed of a rich assemblage of herbivores, fungivores, and their associated predators and parasitoids that function to regulate primary production and nutrient fluxes, the stem zone community that includes bark- and wood-boring species and their associated predators and parasitoids that initiate the decomposition of coarse woody debris, and the forest floor community composed of a variety of detritivores, fungivores, burrowers, and their associated predators and parasitoids that are instrumental in litter decomposition. Insect outbreaks are relatively rare in old-growth forests, where the diversity of resources and predators limit population growth. In turn, insects contribute to plant diversity and limit primary production of host plant species, thereby promoting development of old-growth forest characteristics. Arthropods also provide important functions in decomposition and nutrient cycling that may be lost in younger, managed forests with limited provision of coarse woody debris and accumulated litter. Protection of remnant old-growth forests within the forest matrix may be particularly valuable for maintaining the diversity of plant and arthropod predators that can minimize outbreaks, thereby contributing to resilience to changing environmental conditions.
\end{abstract}

Keywords: insects; defoliators; bark beetles; wood borers; detritivores; predators; biocontrol; conservation; biodiversity

\section{Introduction}

Old-growth forests have been a center of controversy because of their conflicting ecological, political, and social values (e.g., timber harvest vs. biodiversity conservation) [1-3]. Old-growth generally can be described as relatively old and relatively undisturbed [2], but defining old-growth has been problematic, because commercial definitions emphasize the period from first merchantability to culmination of mean annual increment (when wood production efficiency begins to decline), whereas biological definitions emphasize the age at which shade-tolerant later successional tree species begin to attain dominance [3]. A National Research Council (NRC) Committee defined old-growth in the Pacific Northwest as late-successional, with large old trees, significant and increasing dominance by shade-tolerant species, complex, multi-layered canopy structure, abundant standing dead trees, and large coarse woody debris (CWD), and abundant litter on the ground [3]. These characteristics do not apply equally to all old-growth forest types. For example, old-growth longleaf pine, Pinus palustris, forest in the southeastern U.S. and old-growth ponderosa pine, Pinus ponderosa, forest in 
the western U.S. and Canada form relatively pure open-canopied stands maintained historically by frequent fire. Furthermore, these characteristics do not all appear simultaneously, and different forest types acquire these characteristics at different forest ages [1,3]. Therefore, an unambiguous threshold age for becoming old-growth has not been identified. However, old-growth forests generally are $>200$ years old and are relatively undisturbed by human activities [3]. Although old-growth forests may have been spared obvious manipulation, they nevertheless have been affected indirectly by fire suppression, atmospheric pollution, and invasive species. From a timber production perspective, old-growth is considered to be inefficient because of the increasing mortality of large, unharvested trees [2], but from a biodiversity perspective, old-growth provides the greatest diversity of habitats for unique assemblages of species that may not occur or be unable to survive and reproduce in younger forests that lack critical habitats [3]. Consequently, commercial forestry has favored harvesting stands long before old-growth characteristics typically appear, thereby threatening the persistence of species that depend on old-growth habitats [3].

Old-growth forests have been greatly reduced in North America as a result of extensive harvest activities [3]. The NRC Committee Report [3] concluded that in regards to the forested area of the Pacific Northwest, roughly half of which is forested, $54 \%-70 \%$ was old-growth prior to Euro-American settlement, and only 10\%-18\% remains in old-growth status. Latty [4] estimated that $72 \%$ of the land area of northern Michigan and Wisconsin was originally hardwood-hemlock forest and that $64 \%$ of the forested area was old-growth; by comparison, only $17 \%$ of the area remains forested and only $0.5 \%$ is represented by old-growth. Furthermore, remaining old-growth has been greatly fragmented in western North America and only isolated fragments remain in most of eastern North America. Remnant stands often are surrounded by clearcuts that compromise old-growth conditions (e.g., stable temperatures and relative humidities) and threaten persistence of associated species that depend on those conditions [3].

Old-growth forests harbor many associated species that are favored by relatively stable environmental conditions and by the rich diversity of habitats and tree species that do not occur in younger forests. Many of these species may be unable to survive and reproduce in younger or managed forests [3]. Tall multilayered canopies characterizing many old-growth forests have the greatest capacity to buffer interior forest conditions from extreme variation in temperature, moisture, and wind speed $[5,6]$. The relatively moderate conditions characterizing these old-growth forests provide optimal environmental conditions for a diversity of plant and animal species that cannot tolerate greater variation in environmental conditions $[3,6]$. By contrast, harvested or naturally disturbed forests typically are replanted to monocultures of commercially valuable species or regenerate naturally with early successional species that provide less habitat diversity than do old-growth forests [3].

Although efforts to protect increasingly isolated remnants of old-growth forest typically focus on endangered plants and vertebrates, arthropods are equally important to the functioning of forest ecosystems and are vulnerable to extinction through loss of old-growth forests. In fact, the value of old-growth forests may lie primarily in their diversity of native species that provide population sources for colonization and ecological functions in regenerating forests. In particular, the diversity of plant species, predaceous arthropods, and insectivorous vertebrates in old-growth forests help maintain lower abundances of herbivores than often occur in younger, managed, forests [3,7].

Arthropods typically comprise $70 \%-90 \%$ of taxa and dominate animal biomass in forest ecosystems [8,9]. Arthropod diversity generally increases with forest age $[7,10,11]$, time since prior disturbance [9], and the remaining area of forest [10]. Remnant old-growth forests are particularly rich in arthropod biodiversity [7,8]. The number of arthropod species known to be associated with old-growth forests is likely to grow over time as more data become available, given the high diversity of plant species and habitats in these forests. Old-growth arthropods often have limited mobility, and many are flightless, making them vulnerable to forest fragmentation [12,13]. In fact, Roff [13] concluded that flightless species are found in higher frequency in persistent habitats, such as late successional stages, than in earlier successional stages. Furthermore, populations of 
arthropods typically are more stable in old-growth forests than in younger forests [14]. Many species are particularly important in maintaining ecological processes that sustain forest production and ecosystem services $[8,15]$. While many species can survive in younger, managed forests, some may be threatened by disappearance of old-growth forests. However, no previous review has compiled data for old-growth arthropods in North America.

Relatively few studies have addressed old-growth arthropods and fewer have compared arthropod abundances and diversity between old-growth and younger or managed forests. Distinct assemblages characterize old-growth and younger or managed forests, as well as the forest canopy, understory, stem and forest floor zones. Each assemblage has important effects on forest structure and function. This paper reviews data on arthropod diversity and ecological functions in old-growth forests of North America and differences between old-growth and younger, managed forests.

\section{Canopy Zone}

Forest canopies provide a wide variety of temperature and moisture conditions, as well as structurally-complex branching patterns, multi-layered canopy structure, and chemically-distinct foliage qualities of diverse tree species, and may host half of the world's species [6]. Old-growth forests, in particular, typically provide the richest diversity of plant species, habitats, and vertical and horizontal gradients in temperature, moisture, and soil type [6] that, in turn, support the richest diversity of associated herbivores, detritivores, and their predators and parasites, compared to younger forests $[7,11]$. By contrast, younger, managed forests typically are composed of only one or a few commercially-valuable tree species. Not all old forests are diverse, however. In addition to the longleaf pine and ponderosa pine forests noted above, Douglas-fir, Pseudotsuga menziesii, forest can persist as relatively pure, even-aged stands for more than 250 years [3]. Nevertheless, greater tree species and age diversity in later successional forest provides habitat for a greater diversity of arthropods [7]. Relic old-growth forests of the southeastern U.S. (e.g., Great Smoky Mountains) and northwestern U.S. (e.g., Klamath Mountains) are considered biodiversity "hot spots", based on their richest plant species diversities in North America $[8,16]$. This high plant diversity is reflected in high diversity of associated insects and other arthropods. Most herbivorous insects are specialized to various degrees for feeding on particular plant species and plant tissues [9,17-19]. Unfortunately, arboreal communities in old-growth forests, particularly in the eastern U.S., are poorly known, because of the difficulty of accessing forest canopies in remote locations [6,7,11]. Furthermore, heavier equipment (such as canopy cranes, ladders, ropes, malaise traps, nets, and pumps for canopy fogging) is necessary to reach and sample forest canopies. Most research on old-growth forest insects has been conducted in western North America where relatively more old-growth forest can be accessed [7,17-21].

Typically, arthropod communities in old-growth forest canopies can be distinguished from those in younger forests by their greater diversity and by their relatively higher proportions of folivores (e.g., caterpillars, tree crickets, and leaf beetles), arboreal detritivores and fungivores (Collembola and oribatid mites), and predators (e.g., predaceous beetles, true bugs (Hemiptera), and spiders), compared to sap-suckers (e.g., scale insects, aphids, aleyrodids, leafhoppers, and treehoppers (Hemiptera)) and ants, which are more abundant in younger forests $[7,19]$. Although relatively few canopy arthropod species are unique to old-growth forests, more species are found consistently in old-growth than in younger forests. Jeffries [11] identified six herbivore species that were significant indicators of old-growth (122-313 year old) forests in Missouri, compared to six species indicative of young (2-18 year old) and mature (101-111 year old) forests. Similar results have been described from western old-growth forests [7,19]. In particular, old-growth Douglas-fir forests in Oregon had significantly higher diversity and densities of predaceous arthropods, particularly dustywings (Neuroptera: Coniopterygidae), bdellid mites and spiders, and arboreal species of oribatid mites, and lower densities of herbivorous species, as compared to younger forests [7]. A specialized arboreal oribatid mite, Camisia carrolli, was significantly and conspicuously more abundant in old-growth forests than in younger forests [7] (Figure 1). Furthermore, as found for eastern forests [18], distinct arthropod 
assemblages characterize different tree species in old-growth Cascade and Sierran forests, making arthropod species diversity dependent on tree species diversity $[7,17,18,20,21]$.

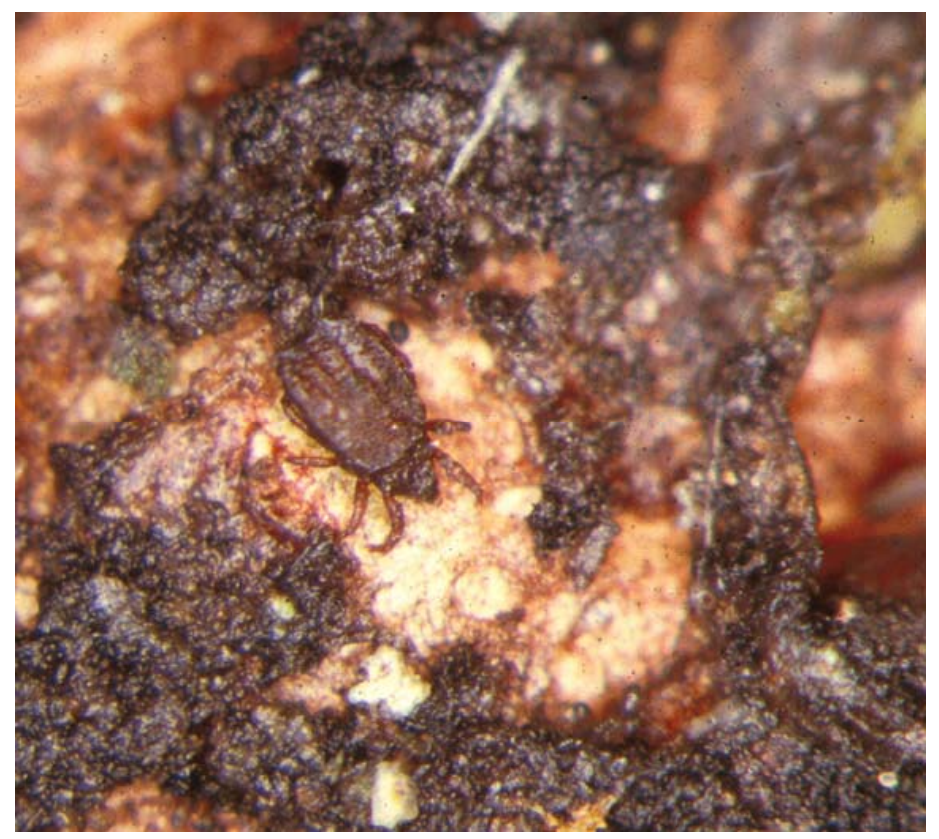

Figure 1. An old-growth canopy specialist, the oribatid mite, Camisia carrolli, feeding on canopy detritus in old-growth canopy in the Pacific Northwest.

The diversity of tree species forces herbivorous insects to contend with the unique defenses characterizing each plant species $[9,22]$. Plant defenses have required varying degrees of specialization by herbivores on particular host plant species, reflecting adaptations to tolerate or avoid defenses. Some herbivores are specialized to colonize only a particular plant species (e.g., the catalpa sphinx, Ceratomia catalpa, found only on catalpa, Catalpa spp., trees) or a few related plant species (e.g., red-humped oakworm, Symmerista canicosta, on related beech, Fagus grandifolia, chestnut, Castanea dentata, and oak, Quercus spp., trees), whereas others (such as the forest tent caterpillar, Malacosoma disstria), are adapted to feed on a wide variety of hardwood species, although local populations may be more restricted in diet breadth [23]. Hemlocks and cedars host particularly unique insect assemblages that complement the community in both eastern and western old-growth forests $[7,17,24,25]$. Typically, insects that feed on angiosperms cannot feed on conifers and vice versa, although some, such as the whitemarked tussock moth, Orgyia leucostigma, and fall webworm, Hyphantria cunea, are capable of doing so.

Accordingly, insects must search for acceptable hosts and typically suffer high mortality in diverse forests as their energy resources are exhausted or they are captured by predators before finding a host [9]. However, stressed or injured plants often suspend production of expensive defensive compounds in order to reallocate limited resources to more immediate survival needs $[9,26]$. Such plants become more vulnerable to a wider variety of herbivore species. If plant stress or injury is widespread across landscapes, small populations of herbivores are able to grow and spread dramatically [9].

Old-growth deciduous forests harbor a richer diversity of herbivorous insects than do old-growth coniferous forests. Whereas the herbivore assemblage on conifers is dominated by aphids, scale insects (Hemiptera), moth (Lepidoptera), and sawfly (Hymenoptera) larvae, the herbivore assemblage on deciduous trees is composed of a richer variety of aphids, scale insects, leafhoppers, treehoppers (all Hemiptera), walkingsticks (Phasmida), tree crickets and katydids, moth larvae, leaf beetles (Chrysomelidae), scarab beetles (Scarabaeidae, especially Phyllophaga spp.), weevils (Curculionidae), 
and leafminers [19]. Among these are the particularly attractive giant silkworm moths, including the cecropia, Hyalophora cecropia, polyphemus, Antheraea polyphemus, and luna, Actius luna, moths.

Old-growth canopies, by virtue of their age, large branches, and complex branching structure, intercept and accumulate substantial soil and litter in perched locations such as branch crotches and treeholes [6]. Additional detrital resources collect on foliage as a result of the development of a phylloplane community (microbial assemblages growing on leaf surfaces) as leaves age. Detritivore and fungivore species associated with these perched soil and detrital resources are distinct from related species associated with the forest floor, which is characterized by more consistently moderate temperature and moisture than is the canopy $[6,9,27]$.

The canopy detritivore/fungivore assemblage is dominated by a variety of arboreal species of Collembola and oribatid mites, such as C. carrolli, Jugatala tuberosa, Platyliodes macroprionus, and Scapheremaeus sp. $[7,20,21,27,28]$. In addition, a number of detritivorous species of cockroaches (Blattaria) and bark lice (Psocoptera) are commonly sampled in old-growth forest canopies [7,17]. Some of these species, particularly cockroaches and crickets, are known to travel at night between the forest floor and canopy [29].

Canopy predators, including beetles (carabids, clerids, fireflies, and ladybird beetles), lacewings (Neuroptera: Chrysididae), true bugs, wasps, bdellid mites, and spiders, are much more diverse in old-growth canopies than in younger forests [7,19]. Spiders are particularly abundant $[7,19,20,28,29]$ and include hunters (such as jumping spiders and ghost spiders), ambushers (such as crab spiders), and web-spinners (such as orb-weavers and long-jawed orb weavers). Hemlocks host a higher diversity of spiders, especially of web-spinners, than do deciduous trees in eastern old-growth forests [25], perhaps because of the greater density of needles and twigs and continuous foliage availability for web support. Predators generally are sufficiently abundant to prevent prey populations from growing substantially, but tend to be relatively ineffective in reducing outbreak populations triggered by environmental changes $[9,30]$.

Many flies and minute wasps in forest canopies are parasitoids. Parasitoids differ from predators in that the attacking individual does not consume its prey but rather deposits eggs or larvae on or in the host; they differ from parasites in that the offspring inevitably kill their host [9]. These insects tend to be highly host-specific, as a consequence of adaptations to avoid or mitigate host immune responses. Therefore, the greater diversity of herbivores, detritivores, fungivores, and even predators, in old-growth forests, compared to managed forests [7,19], supports an even higher diversity of parasitoids. Predators and parasitoids typically are highly mobile, so can be found across landscapes composed of various forest types and ages. Parasitoids must find potential hosts within a complex matrix of habitat types, but tend to be more effective in terminating outbreaks of host herbivores than are more generalist predators [9].

Finally, the production of cones and seeds in old-growth forest canopies provides resources for cone and seed insects. Although younger trees also produce cones, western hemlock, Tsuga heterophylla, does not reach cone-bearing size in old-growth forests until about 150 years after forest establishment [3]. As a result, one undescribed species of seed bug, Kleidocerys sp., has been known almost exclusively from old-growth western hemlock canopies in the Pacific Northwest $[7,20]$.

\section{Understory Zone}

The understory of old-growth forests is composed of a combination of herbs, shrubs, and saplings of shade-tolerant tree species. Understory vegetation supports an arthropod assemblage distinct from that of the overstory $[17,18]$. However, this zone and its associated fauna is often missing from dense, even-aged managed forests because of limited light penetration to the understory.

Flowering species are more abundant in the understory than in the canopy of temperate old-growth forests and may represent significant diversity in conifer-dominated forests. Overstory trees typically are wind-pollinated species, whereas understory plant species that are more isolated and protected from wind must rely on pollination by insects [9]. Understory species in old-growth 
deciduous forests may flower before canopy closure in the spring, relying on early season bumble bees, Bombus spp., that can withstand cooler temperatures, or later in the summer, relying on small bees and flies that find strongly-scented floral resources near the forest floor [8,31]. Ulyshen et al. [32] reported that the bee assemblage in the understory was distinct from that in the canopy of a temperate deciduous forest. Bees were less abundant and diverse in the understory than in the canopy. However, bees likely used the canopy for non-nectar resources, such as honeydew, whereas bees in the understory had access to floral resources.

\section{Stem Zone}

Structural differences between old-growth and younger forests are particularly distinct in the stem zone, where old-growth is characterized by numerous large live and dead stems that provide unique habitats not available in younger forest with smaller stems [1-3]. Insects associated with the stem zone are relatively well-known in older forests because of their economic importance and ease of sampling with standard collecting equipment, such as axes, nets, or simple interception traps (funnel traps or window traps that intercept and collect flying insects). Arthropods in the stem zone shelter in bark crevices, feed on stem-associated fungi (e.g., polypore) or lichens, excavate tunnels in bark or wood, or ascend stems in search of prey [14,29,33-35].

Many insects, especially a variety of beetle and fly species, feed on the conks of shelf or bracket fungi that are instrumental in the decay of coarse woody debris $[29,33,34]$. Because of this association, many of these insects, as well as the fungi on which they feed, are strongly associated with old-growth forests. An ironclad beetle, Phellopsis obcordata (Zopheridae) (Figure 2), is known primarily from old-growth balsam fir, Abies balsamea, and eastern hemlock, Tsuga canadensis, forests in the Appalachian Mountains [34]. On the other hand, Zeran et al. [33] found that sap-feeding nitidulid beetles did not differ significantly in species diversity or abundance between old-growth and younger managed hemlock-mixed hardwood stands in southern Canada.

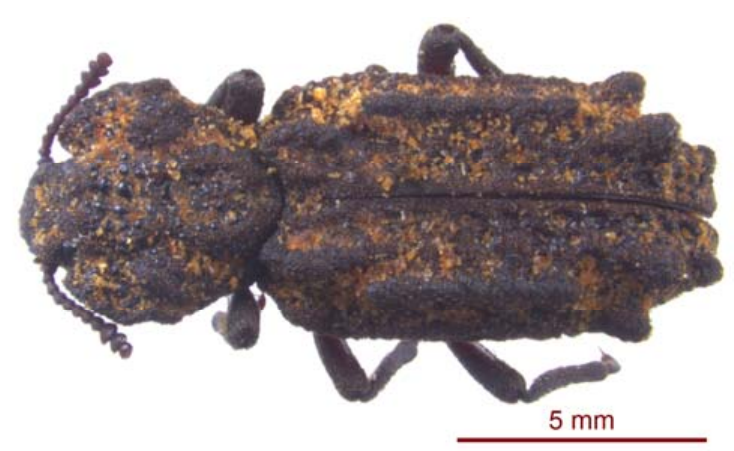

Figure 2. An old-growth specialist, the beetle, Phellopsis obcordata, associated with polypore shelf fungi on the lower boles of large, old balsam fir and hemlock. Courtesy of Michael Ferro, with permission.

A variety of bark beetles and xylophagous insects colonize standing dead or dying trees [35]. These insects are critical for initiating the decomposition and mineralization (release of nutrients as the carbon structure of litter is decomposed) of coarse woody debris by excavating galleries and introducing decay microorganisms across the bark barrier. Release of nutrients and storage of water in coarse woody debris sustain many plant species and maintain primary production $[15,36]$. Key species groups include bark beetles, ambrosia beetles, and wood-boring insects that characterize standing stems.

Bark beetles (Curculionidae) are a diverse group that feeds on subcortical tissues of dead or dying trees. This group is considered to be the most destructive insects in coniferous forests $[9,37,38]$. Some species (including the southern pine beetle, Dendroctonus frontalis, mountain pine beetle, D. ponderosae, and Douglas-fir beetle, D. pseudotsugae) have the capacity to reach large population sizes in patches of stressed or injured hosts and subsequently spread across host-dominated landscapes, 
killing host conifers over large areas [37-39] (e.g., 47 million ha in the western U.S. and Canada during one 10-year period) [38]\}. Outbreaks of these species are self-limiting in naturally diverse old forests composed of relatively sparse hosts, as patches of dense hosts are depleted [37,38]. However, bark beetles may cause localized mortality in old-growth forests where closely-spaced hosts persist, as seen for a group of six large old-growth Douglas-fir killed by Douglas-fir beetles during a drought (1987-1993) in western Oregon (Figure 3). Mortality of colonized hosts thins stands and favors resistant hosts and non-host tree species, thereby reducing the likelihood of future outbreaks and promoting development of old-growth characteristics [40-43].

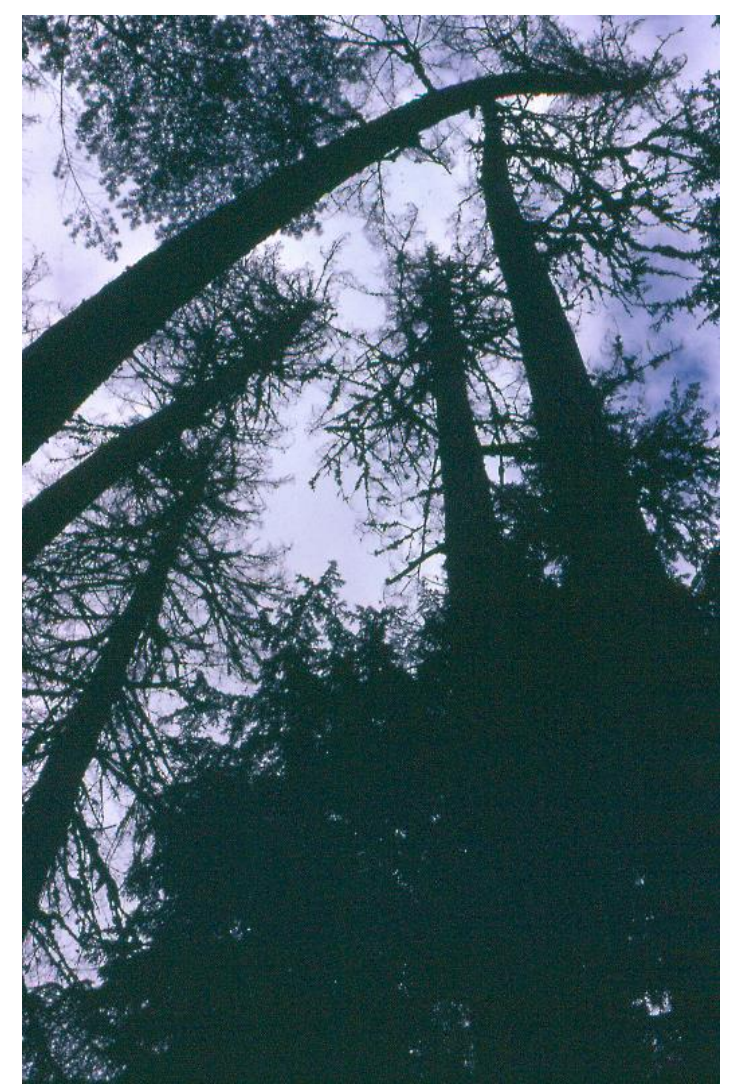

Figure 3. A dense group of six old-growth Douglas-fir trees (500-year-old) at the H.J. Andrews Experimental Forest Long-Term Ecological Research Site in western Oregon killed by Douglas-fir beetles during a drought, 1987-1993.

A variety of other bark beetle species are relatively specific to hardwoods [44]. For example, the hickory bark beetle, Scolytus quadrispinosus, colonizes only hickories, Carya spp., including pecan, Carya illinoienensis.

Most bark beetle species introduce mutualistic, as well as opportunistic, fungi and other microorganisms that provide essential nutrients (e.g., nitrogen and vitamins) for beetle larvae and initiate decomposition of colonized trees. In addition, the galleries of bark beetles and ambrosia beetles provide suitable habitats for a variety of associated mutualistic, commensal, predaceous, and parasitic insects, mites, and other organisms [37,39,40].

Ambrosia beetles (Curculionidae) typically colonize recently dead trees and introduce mutualistic ("ambrosia") fungi into their galleries. Galleries occupy the sapwood, where the adults remain in their tunnels, tending the fungus "gardens" that feed their offspring. These beetles tend to be less specific to particular host species than are bark beetles, because they are affected more by wood moisture than by wood chemistry. Only dead wood with sufficient moisture content (at least $48 \%$ ) is suitable for colonization by most species $[37,44]$. Consequently, larger diameter wood, that retains moisture 
longer, provides the most suitable resources. Nevertheless, the rate of moisture loss, even in large coarse woody debris, is high enough to limit colonization and reproduction by ambrosia beetles to only the first year after tree death $[44,45]$. Declining wood moisture makes older woody debris unsuitable for ambrosia fungi and beetle development [9]. An exception is the Columbian timber beetle, Corthylus columbianus, which colonizes a variety of living deciduous trees, preferring vigorously growing trees of any size [44].

Xylophages characteristic of large standing dead trees reach their greatest abundance and diversity in older forests where standing dead and dying trees are a conspicuous feature and especially in recently-disturbed old-growth with abundant large standing dead trees [46]. Globally, this group (with the exception of ambrosia beetles) has become much less abundant (and many species are threatened or endangered) in fragmented or younger, managed forests where dead wood is less abundant, smaller in diameter, or removed as harvestable biomass, compared to abundancesin old-growth forests $[21,22,46,47]$. Many wood-boring insects, such as wood wasps (Siricidae) and some beetles (especially Buprestidae), also may be abundant in younger forests with coarse woody debris remaining after storms or fires [44]. Some of these species are attracted to sources of smoke, infrared radiation,

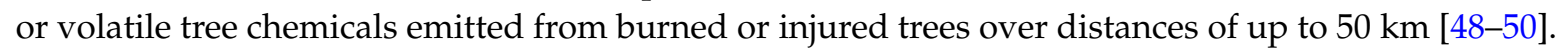
However, without nearby old forests that provide a consistent source of coarse woody debris, these insects will not persist in landscapes dominated by younger forests [46].

Xylophagous insects, including a variety of wood-boring beetles, such as Monochamus spp., wood wasps, Sirex spp., carpenter ants, Camponotus spp., and termites, are instrumental in fragmenting standing dead trees (snags), hastening their fall to the ground, and facilitating their decay and mineralization [9]. Most of the xylophagous beetles and wood wasps colonize only dead wood, but some native species such as the locust borer, Megacyllene robiniae, twolined chestnut borer, Agrilus bilineatus, and bronze birch borer, A. anxius, can colonize and kill stressed or injured trees, hastening their decline and death. Several invasive species, such as the emerald ash borer, A. planipennis, and European wood wasp, Sirex noctilio, colonize and kill living trees. Carpenter ants and subterranean termites, Reticulitermes spp., colonize heartwood of living trees and dead wood in contact with the ground. Most of these insects have mutualistic associations with saprophytic fungi that digest cellulose and enhance the nutritional value of wood tissues [9]. As noted in Section 5, a distinct assemblage of xylophages continues the decomposition of coarse woody debris on the ground.

Important arthropod predators in the stem zone include snakeflies (Neuroptera: Raphidiidae), a variety of clerid, histerid, trogossitid, and monotomid beetles, and parasitic flies and wasps [51]. These predators and parasites are capable of regulating populations of bark- and wood-boring insects, although their importance during outbreaks may show a time delay as a result of slower functional and numerical responses to rapidly-increasing prey availability [30]. In addition, stem-feeding insects provide food resources for a variety of bark-gleaning birds and woodpeckers.

\section{Forest Floor Zone}

Old-growth forests are more likely than younger forests to have deep accumulated litter on the forest floor. This relatively insulated layer provides habitat with relatively stable temperature and moisture content suitable for a high diversity of arthropods associated with decomposition of this material $[3,15,51]$. Younger forests with less accumulated litter are subject to greater variation in forest floor temperature and moisture [52]. Arthropods associated with the forest floor are instrumental in the inoculation of litter with microorganisms that are responsible for litter decomposition and release of nutrients that become available for new plant growth and help sustain primary production $[4,15,36,52]$. Most data for arthropods associated with old-growth forests are from the forest floor, given the relative accessibility and simple collecting equipment (e.g., cloth bags, pitfall traps, and soil coring tools) necessary to sample this habitat.

Forest floor arthropods can be divided into macroarthropods ( $>10 \mathrm{~mm}$, such as many spiders, millipedes, and beetles), and microarthropods ( $<5 \mathrm{~mm}$, including springtails (Collembola), fly larvae 
(Diptera), oribatid mites and immature and other small arthropods) [15]. Millipedes and some beetle species, including some tenebrionids and ptilodactylids, are true detritivores that feed directly on litter and facilitate fragmentation and increase surface area for microbial colonization. Most species of beetles, flies, springtails, and oribatids are primarily fungivorous or bacteriovorous (feeding on fungi or bacteria, respectively), as required to obtain sufficient nutrition from decaying organic resources that are low in essential nutrients [15]. Spiders, carabid and staphylinid beetles, and ants are important predators.

Many forest floor species are old-growth specialists that depend on the consistent cool, moist conditions provided by abundant accumulated litter under deep, multilayered canopies. These species typically are absent in younger forests due to greater variation in abiotic conditions in a thin layer of litter. Chandler and Peck [53] identified one leiodid beetle, Anisotoma inops, as a potential indicator species for old-growth forests in New Hampshire, although this study compared only two sites, one old-growth vs. one selectively logged in the 1940s. Lamoncha [54] sampled oribatid mites in two aggrading forests at Coweeta Hydrologic Laboratory in southwestern North Carolina and three nearby old-growth forests in North and South Carolina. Species richness and evenness were higher at the old-growth sites. However, although the old-growth sites shared some oribatid species in common, and shared some species with the Coweeta sites, they generally were distinct from one another, as might be expected, given the limited mobility of these organisms [12]. Moldenke and Lattin [12] similarly reported that soil arthropod diversity is higher in old-growth Douglas-fir forests in Oregon.

Burrowers include termites and ants, as well as adults or larvae of some beetles and other arthropods. Social insects can excavate large volumes of soil (up to many cubic meters). This activity mixes soil and litter, aerates soil, and increases infiltration of water $[9,15]$. Therefore, these organisms are instrumental in determining patterns of soil structure, moisture, and fertility.

Wood-boring (xylophagous) insects are particularly diverse in old-growth forests, given their positive association with the size and abundance of CWD (see $[55,56]$ for data from Finland and Japan, respectively). Parsons et al. [51] listed more than 150 species of arthropods associated with coarse woody debris, primarily from large CWD in old-growth coniferous forest. The Pacific dampwood termite, Zootermopsis angusticollis, is abundant in wet coastal old-growth forests, frequently colonizing large CWD within the first two years on the ground and contributing to decomposition throughout the decay process [51]. Species associated with the primary excavating insects include fungivorous commensals (termitophilous species, especially staphylinid and carabid beetles that intercept food from termites or feed in the galleries) and predators. Many of these species do not occur in younger forests with smaller, drier, and less abundant coarse woody debris [57].

Many insect species are associated with particular stages of wood decay. For example, some wood-boring beetles and wood wasps typically occur in recently fallen trees, whereas other beetles, such as the hairy pine borer, Tragosoma depsarius, and Prionus pocularis, and the eastern Hercules beetle, Dynastes tityus, are typically associated with wood in advanced stages of decay, and powderpost beetles (Anobiidae, Lyctidae and Bostrichidae) are responsible for final fragmentation of wood into fine powder that is incorporated into soil. Psallid beetles in the southeastern U.S. and two ancient wood roach species, Cryptocercus punctulatus in the southeastern U.S. and C. clevelandi in the northwestern U.S., are subsocial insects that excavate galleries in late decay classes of coarse woody debris [58]. This disjunct geographical distribution reflects their association with relict forests protected from glaciation. Given their association with late-stage decay of coarse woody debris, these species are primarily associated with late successional and old-growth forests.

Ferro et al. [59] reported that beetle diversity increased from 70 species in decay class 1 (recently dead, twigs present, bark still attached) to 107 species in decay class 2 (twigs absent, bark still attached), then declined to 84 species in decay class 3-4 (inner bark largely consumed, bark sloughing off; bark absent, cross-section becoming oval, respectively), and Ferro et al. [60] found 111 beetle species in decay class 5 (most advanced decay class, bark absent, porous texture, flattened cross-section) in the Great Smoky Mountains National Park. Species richness was similar between primary and secondary 
forests for decay classes $1-4$, but was significantly higher in secondary forests than in primary forests for decay class 5 . However, more species were significantly associated with primary than secondary forests. Of 71 species with sufficient numbers for testing, 16 (23\%) were represented by significantly more specimens in secondary forests, 27 (38\%) were represented by significantly more specimens in primary forests, and $28(39 \%)$ showed no significant difference between the two forest types.

Xylophagous insects are instrumental in the breakdown of CWD on the ground $[45,61,62]$. Through the excavation of galleries and inoculation of wood with microorganisms, decomposing wood gradually becomes a sponge that represents a "hot spot" for water and nutrients and may be critical to germination and growth of many plant species (e.g., nurse logs) [3,62]. In addition to the critical role of these insects in wood fragmentation and inoculation of saprophagous microorganisms that are instrumental in wood decay, a variety of key wildlife species, including woodpeckers and bears, excavate wood in search for these insects.

Predators on the forest floor include a variety of ground beetles (Carabidae), firefly (Lampyridae) and glowworm (Phengodidae) larvae, ants, and spiders. Carabid beetles have been a focus of several studies because of relatively good taxonomic resolution. Latty et al. [4] found that forest floor arthropod assemblages in old-growth were distinct from assemblages in younger, managed forests and identified five carabid species (including Carabus sylvosus, Agonum gratiosum, Myas cyanescens and Platynus decentis) that were significant indicators of old-growth forests in northern Wisconsin and Upper Michigan, compared to two significant indicators of younger, managed forests (Harpalus fulvilabris and Pterostichus coracinus) (Figure 4). Willett [63] found that the diversity and abundance of spiders also was greater in stands of old-growth redwood, Sequoia sempervirens, compared to 100 year old or younger stands. Work [64] identified distinct assemblages of carabid and staphylinid beetles, ants, and spiders that characterized interior old-growth coniferous forest ( $>100 \mathrm{~m}$ from clearcut edge), edge, and replanted clearcut in western Oregon. In particular, the staphylinid, Tachinus semirufus, carabids, Zacotus matthewsii, Pterostichus herculaneus, Scaphinotus angusticollis, and S. marginatus, and leptodirid, Catops basilaris, were significantly most abundant $>100 \mathrm{~m}$ into old-growth forest. These data are supported by results of studies of ants in Finland [65].

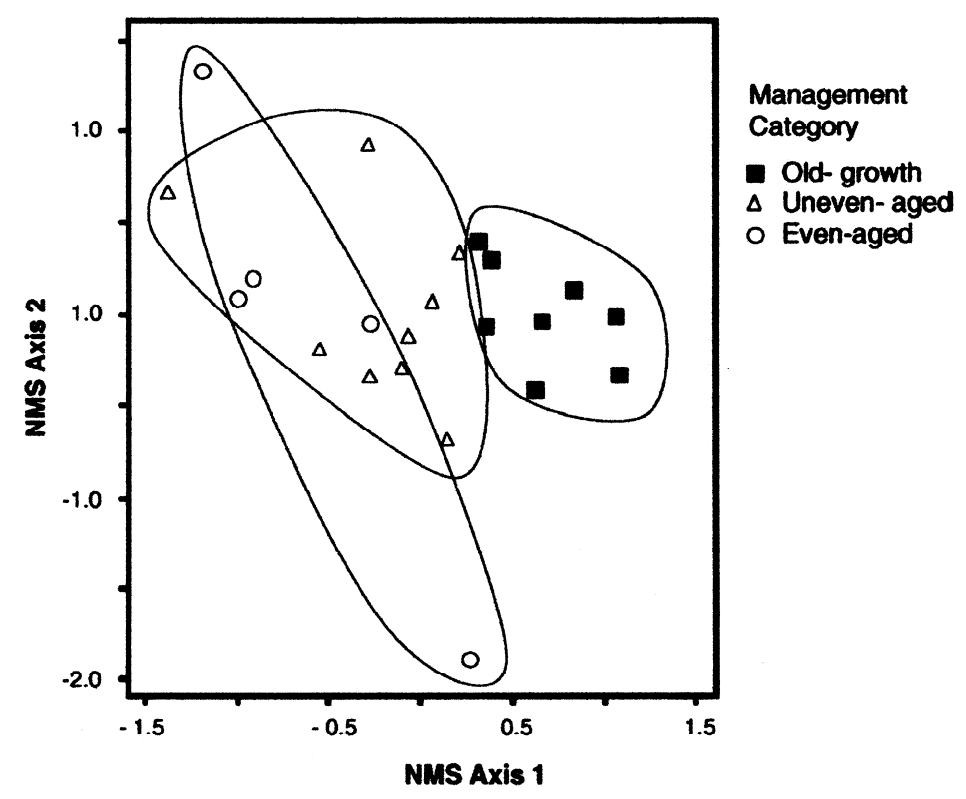

Figure 4. Nonmetric multidimensional scaling (NMS) ordination of carabid beetle diversity in old-growth, uneven-, and even-aged eastern hardwood-hemlock forests in northern Wisconsin and Upper Michigan, showing the association of study sites (stands) in species space. The separation of old-growth (black squares) from the younger, managed forests indicates that old-growth forests support a distinct carabid assemblage. From [4] with permission from Elsevier. 


\section{Outbreaks}

Abundances of various species change over time as environmental conditions change. Drought or storm damage, in particular, can trigger outbreaks of folivores, such as eastern spruce budworm, Choristoneura fumiferana, western spruce budworm, C. occidentalis, and Douglas-fir tussock moth, Orgyia pseudotsugata, and bark beetles, such as southern and mountain pine beetles, when host trees are stressed and/or abundant or when predator and parasite abundances are reduced $[7,9,66,67]$ (Figure 5). Increased bundance of white fir, Abies concolor, resulting from fire suppression in old-growth mixed-conifer forest in California led to water limitation and outbreak of Douglas-fir tussock moth [9] (Figure 5). However, the diversity of tree species in old-growth forests typically maintains more stable populations and lower levels of defoliation, compared to younger, especially managed, forests dominated by host species [7,9].

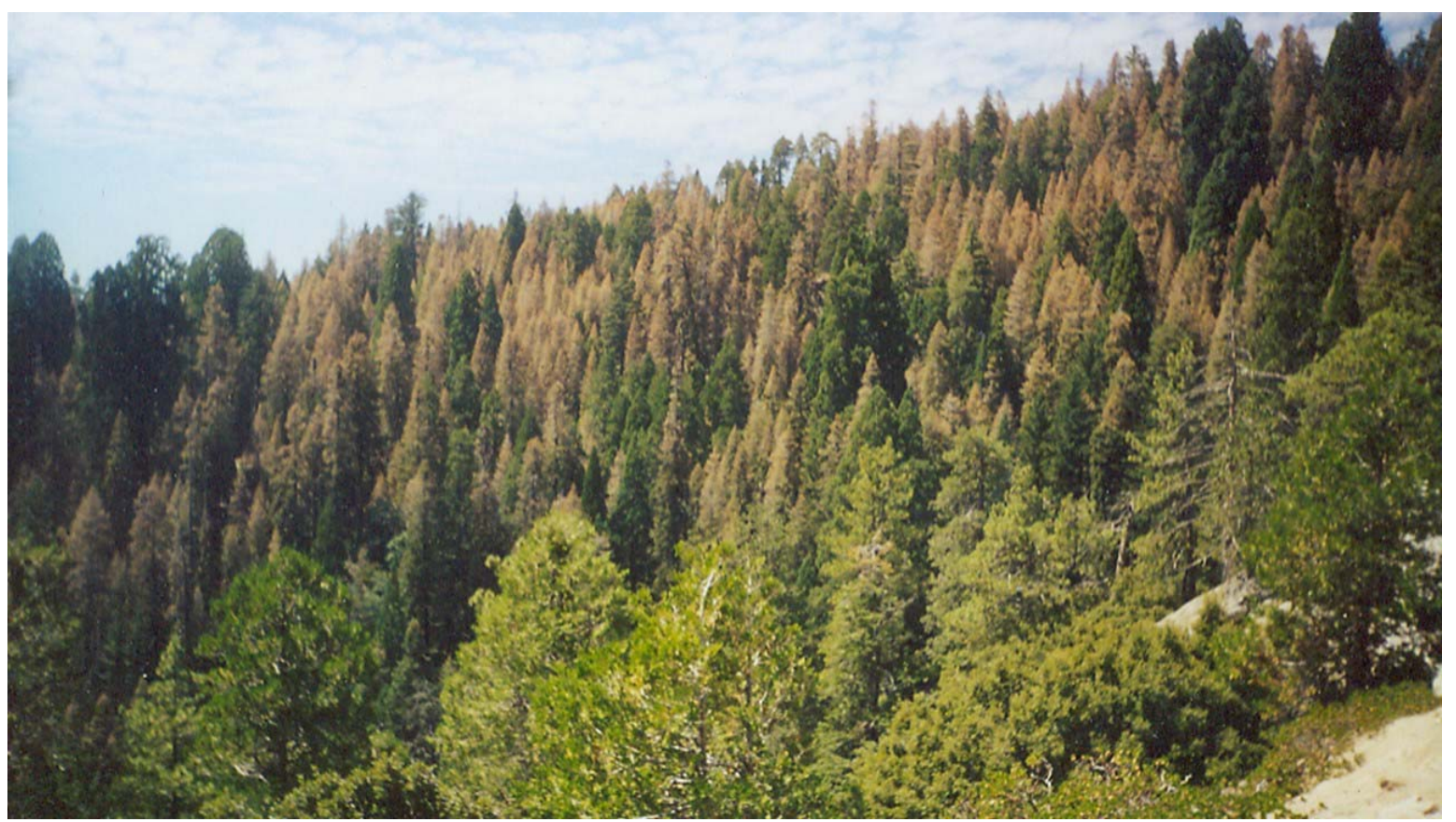

Figure 5. Understory white fir, Abies concolor, the late successional dominant in high-elevation Sierran forests, is increasingly stressed by competition for water in arid lower-elevation forests, where it has increased in density as a result of fire suppression. An outbreak of the Douglas-fir tussock moth, Orgyia pseudotsugata, on dense, stressed hosts during 1997-1998 completely defoliated the white fir (brown, defoliated trees), returning dominance to 2000-year-old, drought- and fire-tolerant sequoias, Sequoiadendron giganteum (the tallest green, foliated trees), and $>300$-year-old pines, Pinus spp. From [9] with permission from Elsevier.

Outbreaks of native insect species are relatively rare and localized in old-growth forests characterized by high diversity and low density of suitable resources (e.g., plant tissues with acceptable concentrations of nutrients and defensive compounds, as described above) and high diversity of predators and parasites [7,9] (Figures 3 and 5). Outbreaks occur in old-growth forests that are less diverse, such as in boreal forests where widespread outbreaks of spruce beetle, Dendroctonus rufipennis, have occurred in dense old spruce, Picea spp., forests and of mountain pine beetle in dense old ponderosa pine forests stressed by drought and warming temperatures $[41,42,66,67]$. Outbreaks occur more frequently in younger, especially managed, forests dominated by host tree species, often even-aged and with few non-hosts to interrupt population growth [7,41,42]. Outbreaks are triggered by environmental changes that stress trees and inhibit production of plant defenses, that promote increased density of host plant species, or that reduce abundances of predators [9,30,40-42]. Drought 
and storm conditions are particularly important triggers for outbreaks $[9,26,38,67]$ (Figure 5). If high density and/or stress of host species are widespread over landscapes that have been converted to younger, usually less diverse, managed forests, then growing insect populations may spread over large areas $[9,37,38,41,44,67]$.

Normally, outbreaks are concentrated on one or a few host tree species and are self-limiting (i.e., outbreaks typically decline in 3-4 years when suitable food resources are depleted and/or increased predation or epizootics of diseases are induced) $[43,61]$. However, a few species, such as the forest tent caterpillar, have broad host range and can affect a greater proportion of the forest, although outbreaks of such species also typically last 3-4 years, as epizootics reduce population size.

Outbreaks are not necessarily destructive, from an ecological perspective. Outbreaks typically prune, thin, and diversify forests (i.e., help to create old-growth conditions) $[9,42,43,68]$. For example, Douglas-fir beetle and Douglas-fir tussock moth accelerate the transition from Douglas-fir forest to old-growth hemlock forests in the Pacific Northwest [9,69]. Furthermore, defoliation may improve tree survival during drought [69], and surviving trees typically grow faster for decades following outbreaks [66,70,71]. Finally, outbreaks focused on stressed trees shift tree species dominance toward species better adapted to prevailing conditions $[9,72,73]$. This mechanism for community adjustment may become more important as warming temperatures stress additional tree species and increase the frequency and duration of outbreaks [31,66,67,69].

\section{Invasive Arthropod Species}

A number of invasive species have become naturalized in old-growth forests. Invasive species have escaped regulatory mechanisms that operated in their native ecosystems. Such species have the capacity to continue to find new hosts in enemy-free space and can virtually eliminate host species from forest ecosystems. Some, such as the Asiatic oak weevil, Cyrtepistomus castaneus, are relatively inconspicuous, whereas others, such as the gypsy moth, Lymantria dispar, and hemlock wooly adelgid, Adelges tsugae, have caused dramatic changes in forest structure and function by largely eliminating dominant tree species [74-76]. Some, such as the hemlock woolly adelgid and emerald ash borer, threaten not only the persistence of their host tree species in old-growth forests, but also threaten arthropod species that are restricted in habitat to that tree species $[77,78]$.

\section{Arthropod Functions in Old-Growth}

Arthropods have important functional roles in old-growth forests, as well as in other ecosystems [9,68,79-81]. Arthropods are primary factors affecting turnover of plant material, nutrients, and water. Herbivore tissues, feces, green foliage fragments, and throughfall (precipitation percolating through the forest canopy) provide more consistent supply of nutrients to the forest floor community, for eventual uptake by plants, than would occur in their absence [9,79-81]. Detritivores initiate the process of decomposition by fragmenting and inoculating detritus with saprophagous microorganisms $[9,15]$ and are instrumental in the return of nutrients to soil for uptake by plants and production of new plant tissues $[9,15,81]$. Decomposition is delayed in the absence of arthropod detritivores and fungivores $[9,61,68]$. These processes are critical to sustained primary production [36], although fertilization could accomplish this goal at great expense.

Herbivorous arthropods are more abundant in younger forests but more diverse in older forests, especially when tree diversity is higher in old-growth [7,19]. Therefore, herbivory often is higher in younger forests $[7,9,17]$. Although herbivorous arthropods typically are viewed as destructive agents, especially during outbreaks (see section 6), the low-to-moderate levels of herbivory characterizing old-growth forests may regulate plant populations near carrying capacity and induce compensatory production of new plant tissues, depending on availability of sufficient water and nutrients $[9,69-71,82,83]$. Outbreaks alter community structure, depending on which tree species are stressed or have reached high density following environmental changes [9,42,43,66,72] (see Figure 5). Suppressed growth and/or mortality of targeted host plant species favor their replacement by plants 
or plant species that are more tolerant of the altered conditions or use limited resources more efficiently $[9,42,43,66,72]$. Although these effects conflict with timber management objectives [2,3], the more diverse historic conditions of Western forests were less prone to outbreaks and are the current management recommendations for southern and western conifer forests in the U.S. $[9,42,43,84,85]$.

Younger, managed forests have lower abundances and diversity of detritivores, fungivores and xylophages, than do old-growth forests, because of the virtual absence of large CWD and less litter accumulation $[15,57,68]$. Therefore, younger forests have less water storage and nutrient availability than do older forests $[57,61,68]$. Xylophages introduce a diversity of saprophagous fungi and bacteria, including nitrogen-fixing species, into decomposing wood, thereby accelerating decomposition and fluxes of nutrients, especially nitrogen, to the forest floor $[57,61,68]$. Litter and CWD become more porous and capable of holding more water as they decompose [68]. Younger forests are less able to store water in litter during dry periods and are relatively impoverished in sources of nitrogen without the major contribution from decomposing CWD and its associated fauna [68].

Furthermore, the high abundance and diversity of arthropod predators associated with old-growth forests are largely responsible for preventing outbreaks of herbivorous insects [7,9,30]. A greater diversity of predators and parasites maximizes regulation of prey populations, because different predator and parasite species attack different life stages of their prey, thereby preventing prey escape in time or space $[9,68]$. Spiders, in particular, are more abundant and diverse in old-growth forest canopies than in younger forests $[7,17,19,20]$. The diversity of arthropod species also provides resources for a variety of vertebrate predators (especially birds and small mammals). The reduced diversity of predators in young, managed forests potentially increases the risk of herbivore outbreaks $[7,9,30]$. Thus, retention of old-growth forests within the landscape could contribute to pest management goals, as well as other ecosystem services, in old-growth and non-old-growth stands.

\section{Conclusions}

Arthropods comprise a bulk of diversity and contribute to critical functions in old-growth forests in North America. Although assemblages vary by region and forest type, distinct arthropod assemblages generally characterize old-growth and younger or managed forests in eastern and western North America. However, relatively few species appear to be unique to old-growth. Rather, many, perhaps most, species found in old-growth also can be found in younger forest. Nevertheless, many species remain unidentified and their old-growth status is unknown. Species identified as indicators of old-growth likely are sufficiently specialized that they will be threatened if (1) optimal habitats in old-growth are lost and (2) survival and reproduction in younger forest are insufficient to maintain their populations.

A number of arthropod species in the canopy (oribatid mites, predators, and parasitoids), stem (xylophages and polypore fungus feeders), and forest floor (xylophages and carabid beetles) zones reach peak abundances in old-growth because of the unique habitats (large old trees, large CWD and deep litter) and stable, moderate temperature and relative humidity that characterize old-growth forests, in contrast to younger, managed forests. Arthropods, like other animals, may move across landscapes as they forage or disperse but may not be able to survive and reproduce in all forest types if their resources or habitats are absent. Consequently, many arthropods may be vulnerable to extinction as old-growth forests continue to disappear, potentially threatening nutrient cycling processes critical to forest productivity. Old-growth forests host a particularly rich diversity of predators and parasitoids that contribute to regulation of prey populations. As a result, insect outbreaks are relatively rare in diverse old-growth forests but occur more frequently in less diverse forests where they are an important mechanism for thinning and diversifying vegetation, thereby contributing to development of old-growth characteristics. The value of old-growth forests as reservoirs for diverse assemblages of arthropods (especially predators and parasitoids) that can spread from old-growth to surrounding forest types may contribute to management goals across forested landscapes in much the same way 
that fire is now used as a tool in many forestry applications. In this way, both timber production and old-growth conservation goals may be accomplished.

Acknowledgments: This paper was supported by USDA Hatch funding. This manuscript is published with the approval of the Director of the Louisiana Agricultural Experiment Station, as manuscript number 2016-234-30580.

Conflicts of Interest: The authors declare no conflict of interest.

\section{References}

1. Pesklevits, A.; Duinker, P.N.; Bush, P.G. Old-growth forests: Anatomy of a wicked problem. Forests 2011, 2, 343-356. [CrossRef]

2. Hunter, M.L. What constitutes an old-growth stand? J. For. 1989, 86, 33-35.

3. Christensen, N.L., Jr.; Gregory, S.V.; Hagenstein, P.R.; Heberlein, T.A.; Hendee, J.C.; Olson, J.T.; Peek, J.M.; Perry, D.A.; Schowalter, T.D.; Sullivan, K.; et al. Environmental Issues in Pacific Northwest Forest Management; National Academy Press: Washington, DC, USA, 2000.

4. Latty, E.F.; Werner, S.M.; Mladenoff, D.J.; Raffa, K.F.; Sickley, T.A. Response of ground beetle (Carabidae) assemblages to logging history in northern hardwood-hemlock forests. For. Ecol. Manag. 2006, 222, 335-347. [CrossRef]

5. Parker, G.G. Structure and microclimate of forest canopies. In Forest Canopies; Lowman, M.D., Nadkarni, N.M., Eds.; Academic Press: San Diego, CA, USA, 1995; pp. 73-106.

6. Lowman, M.D.; Schowalter, T.D.; Franklin, J.F. Methods in Forest Canopy Research; University of California Press: Berkeley, CA, USA, 2006.

7. Schowalter, T.D. Canopy arthropod communities in relation to forest age and alternative harvest practices in western Oregon. For. Ecol. Manag. 1995, 78, 115-125. [CrossRef]

8. Sharkey, M.J. The all taxa biological inventory of the Great Smoky Mountains National Park. Fla. Entomol. 2001, 84, 556-564. [CrossRef]

9. Schowalter, T.D. Insect Ecology: An Ecosystem Approach, 4th ed.; Elsevier/Academic: San Diego, CA, USA, 2016.

10. Summerville, K.S.; Crist, T.O. Contrasting effects of habitat quantity and quality on moth communities in fragmented landscapes. Ecography 2004, 27, 3-12. [CrossRef]

11. Jeffries, J.M.; Marquis, R.J.; Forkner, R.E. Forest age influences forest insect herbivore community structure, richness, and diversity. Ecol. Appl. 2006, 16, 901-912. [CrossRef]

12. Moldenke, A.R.; Lattin, J.D. Dispersal characteristics of old-growth soil arthropods: The potential for loss of diversity and biological function. Northw. Environ. J. 1990, 6, 408-409.

13. Roff, D.A. The evolution of flightlessness in insects. Ecol. Monogr. 1990, 60, 389-421. [CrossRef]

14. Heyborne, W.H.; Miller, J.C.; Parsons, G.L. Ground dwelling beetles and forest vegetation change over a 17-year-period, in western Oregon, USA. For. Ecol. Manag. 2003, 179, 123-134. [CrossRef]

15. Coleman, D.C.; Crossley, D.A., Jr.; Hendrix, P.F. Fundamentals of Soil Ecology, 2nd ed.; Elsevier: Amsterdam, The Netherlands, 2004.

16. Sawyer, J.O. Northwest California: A Natural History; University of California Press: Berkeley, CA, USA, 2006.

17. Schowalter, T.D.; Zhang, Y.L. Canopy arthropod assemblages in four overstory and three understory plant species in mixed-conifer old-growth forest in California. For. Sci. 2005, 51, 233-242.

18. Schowalter, T.D.; Zhang, Y.L.; Progar, R.A. Canopy arthropod response to density and distribution of green trees retained after partial harvest. Ecol. Appl. 2005, 15, 1594-1603. [CrossRef]

19. Schowalter, T.D.; Crossley, D.A., Jr. Canopy arthropods and their response to forest disturbance. In Forest Hydrology and Ecology at Coweeta; Swank, W.T., Crossley, D.A., Jr., Eds.; Springer: New York, NY, USA, 1988; pp. 207-218.

20. Schowalter, T.D.; Ganio, L.M. Vertical and seasonal variation in canopy arthropod communities in an old-growth conifer forest in southwestern Washington, USA. Bull. Entomol. Res. 1998, 88, 633-640. [CrossRef]

21. Rambo, T.; Schowalter, T.; North, M. Canopy arthropod responses to thinning and burning treatments in old-growth mixed-conifer forest in the Sierra Nevada, California. For. Ecol. Manag. 2014, 326, 91-100. [CrossRef]

22. Harborne, J.B. Introduction to Ecological Biochemistry, 4th ed.; Academic Press: London, UK, 1994. 
23. Parry, D.; Goyer, R.A. Variation in the suitability of host tree species for geographically discrete populations of forest tent caterpillar. Environ. Entomol. 2004, 33, 1477-1487. [CrossRef]

24. Dilling, C.; Lambdin, P.; Grant, J.; Buck, L. Insect guild structure associated with eastern hemlock in the southern Appalachians. Environ. Entomol. 2007, 36, 1408-1414. [CrossRef]

25. Mallis, R.E.; Rieske, L.K. Arboreal spiders in eastern hemlock. Environ. Entomol. 2011, 40, $1378-1387$. [CrossRef] [PubMed]

26. Hunter, M.D.; Forkner, R.E. Hurricane damage influences foliar polyphenolics and subsequent herbivory on surviving trees. Ecology 1999, 80, 2676-2682. [CrossRef]

27. Winchester, N.N. Ancient temperate rain forest research in British Columbia. Can. Entomol. 2006, 138, 72-83. [CrossRef]

28. Moldenke, A.R.; Fichter, B.L. Invertebrates of the H.J. Andrews Experimental Forest, Western Cascade Mountains, Oregon: IV. The Oribatid Mites (Acari: Cryptostigmata); Gen. Tech. Rpt. PNW-GTR-217; USDA Forest Service Pacific Northwest Research Station: Portland, OR, USA, 1988.

29. Hanula, J.L.; Franzrb, K. Source, distribution and abundance of macroarthropods on the bark of longleaf pine: Potential prey of the red-cockaded woodpecker. For. Ecol. Manag. 1998, 102, 89-102. [CrossRef]

30. Turchin, P.; Taylor, A.D.; Reeve, J.D. Dynamical role of predators in population cycles of a forest insect: An experimental test. Science 1999, 285, 1068-1071. [CrossRef] [PubMed]

31. Kudo, G.; Ida, T.Y.; Tani, T. Linkages between phenology, pollination, photosynthesis, and reproduction in deciduous forest understory plants. Ecology 2008, 89, 321-331. [CrossRef] [PubMed]

32. Ulyshen, M.D.; Soon, V.; Hanula, J.L. On the vertical distribution of bees in a temperate deciduous forest. Insect Conserv. Divers. 2010, 3, 222-228. [CrossRef]

33. Zeran, R.M.; Anderson, R.S.; Wheeler, T.A. Sap beetles (Coleoptera: Nitidulidae) in managed and old-growth forests in southeastern Ontario, Canada. Can. Entomol. 2006, 138, 123-137. [CrossRef]

34. Foley, I.A.; Ivie, M.A. A revision of the genus Phellopsis LeConte (Coleoptera: Zopheridae). Zootaxa 2008, 1689, 1-28.

35. Howden, H.F.; Vogt, G.B. Insect communities of standing dead pine (Pinus virginiana Mill.). Ann. Entomol. Soc. Am. 1951, 44, 581-595. [CrossRef]

36. Wood, T.E.; Lawrence, D.; Clark, D.A.; Chazdon, R.L. Rain forest nutrient cycling and productivity in response to large-scale litter manipulation. Ecology 2009, 90, 109-121. [CrossRef] [PubMed]

37. Furniss, R.L.; Carolin, V.M. Western Forest Insects; Misc. Publ. 1339; USDA Forest Service: Washington, DC, USA, 1977.

38. Raffa, K.F.; Aukema, B.H.; Bentz, B.J.; Carroll, A.L.; Hicke, J.A.; Turner, M.G.; Romme, W.H. Cross-scale drivers of natural disturbances prone to anthropogenic amplification: The dynamics of bark beetle eruptions. BioScience 2008, 58, 501-517. [CrossRef]

39. Coulson, R.N.; Klepzig, K.D. (Eds.) Southern Pine Beetle II; Gen. Tech. Rpt. SRS-140; USDA Forest Service Southern Research Station: Asheville, NC, USA, 2011.

40. Schowalter, T.D. Ecology and management of bark beetles (Coleoptera: Curculionidae: Scolytinae) in southern pine forests. J. Integr. Pest Manag. 2012, 3, A1-A7. [CrossRef]

41. Schowalter, T.D.; Turchin, P. Southern pine beetle infestation development: Interaction between pine and hardwood basal areas. For. Sci. 1993, 39, 201-210.

42. Cairns, D.M.; Lafon, C.L.; Waldron, J.D.; Tchakerian, M.; Coulson, R.N.; Klepzig, K.D.; Birt, A.G.; Xi, W. Simulating the reciprocal interaction of forest landscape structure and southern pine beetle herbivory using LANDIS. Landsc. Ecol. 2008, 23, 403-415. [CrossRef]

43. Coleman, T.W.; Clarke, S.R.; Meeker, J.R.; Rieske, L.K. Forest composition following overstory mortality from southern pine beetle and associated treatments. Can. J. For. Res. 2008, 38, 1406-1418. [CrossRef]

44. Drooze, A.T. Insects of Eastern Forests; Miscellaneous Publication No. 1426; USDA Forest Service: Washington, DC, USA, 1985.

45. Zhong, H.; Schowalter, T.D. Conifer bole utilization by wood-boring beetles in western Oregon. Can. J. For. Res. 1989, 19, 943-947. [CrossRef]

46. Grove, S.J. Saproxylic insect ecology and the sustainable management of forests. Annu. Rev. Ecol. Syst. 2002, 33, 1-23. [CrossRef] 
47. Persiani, A.M.; Audicio, P.; Lunghini, D.; Maggi, O.; Granito, V.M.; Biscaccianti, A.B.; Chiavetta, U.; Marchetti, M. Linking taxonomical and functional biodiversity of saproxylic fungi and beetles in broad-leaved forests in southern Italy with varying management histories. Plant Biosyst. 2010, 144, 250-261. [CrossRef]

48. Evans, W.G. Perception of infrared radiation from forest fires by Melanophila acuminata de Geer (Buprestidae, Coleoptera). Ecology 1966, 47, 1061-1065. [CrossRef]

49. Raffa, K.F.; Phillips, T.W.; Salom, S.M. Strategies and mechanisms of host colonization by bark beetles. In Beetle-Pathogen Interactions in Conifer Forests; Schowalter, T.D., Filip, G.M., Eds.; Academic Press: London, UK, 1993; pp. 103-128.

50. Wickman, B.E. Attack habits of Melanophila consputa on fire-killed pines. Pan-Pac. Entomol. 1964, 40, $183-186$.

51. Parsons, G.L.; Cassis, G.; Moldenke, A.R.; Lattin, J.D.; Anderson, N.H.; Miller, J.C.; Hammond, P.; Schowalter, T.D. Invertebrates of the H.J. Andrews Experimental Forest, Western Cascade Range, Oregon. V. An Annotated List of Insects and Other Arthropods; Gen. Tech. Rpt. PNW-GTR-290; US Forest Service Pacific Northwest Research Station: Portland, OR, USA, 1991.

52. Seastedt, T.R.; Crossley, D.A., Jr. Nutrients in forest litter treated with naphthalene and simulated throughfall: A field microcosm study. Soil Biol. Biochem. 1983, 15, 159-165. [CrossRef]

53. Chandler, D.S.; Peck, S.B. Diversity and seasonality of leiodid beetles (Coleoptera: Leiodidae) in an old-growth and a 40-year-old forest in New Hampshire. Environ. Entomol. 1992, 21, 128-129. [CrossRef]

54. Lamoncha, K.L. Spatial and Temporal Variation in Abundance and Diversity of Soil Oribatida in Southeastern Appalachian Forests. Master's Thesis, University of Georgia, Athens, GA, USA, 1994.

55. Martikainen, P.; Siitonen, J.; Punttila, P.; Kaila, L.; Rauh, J. Species richness of Coleoptera in mature managed and old-growth boreal forests in southern Finland. Biol. Conserv. 2000, 94, 199-209. [CrossRef]

56. Maeto, K.; Sato, S.; Miyata, H. Species diversity of longicorn beetles in humid warm temperate forests: The impact of forest management practices on old-growth forest species in southwestern Japan. Biodivers. Conserv. 2002, 11, 1919-1937. [CrossRef]

57. Schowalter, T.D.; Caldwell, B.A.; Carpenter, S.E.; Griffiths, R.P.; Harmon, M.E.; Ingham, E.R.; Kelsey, R.G.; Lattin, J.D.; Moldenke, A.R. Decomposition of fallen trees: Effects of initial conditions and heterotroph colonization rate. In Ecological Management of Tropical Ecosystems; Singh, K.P., Ed.; Wiley Eastern, Ltd.: New Delhi, India, 1992; pp. 371-381.

58. Maekawa, K.; Nalepa, C.A. Biogeography and phylogeny of wood-feeding cockroaches in the genus. Cryptocercus Insects 2011, 2, 354-368. [CrossRef] [PubMed]

59. Ferro, M.L.; Gimmel, M.L.; Harms, K.E.; Carlton, C.E. Comparison of Coleoptera emergent from various decay classes of downed coarse woody debris in Great Smoky Mountains National Park, USA. Insecta Mundi 2012, 0260, 1-80.

60. Ferro, M.L.; Gimmel, M.L.; Harms, K.E.; Carlton, C.E. Comparison of the Coleoptera communities in leaf litter and rotten wood in Great Smoky Mountains National Park, USA. Insecta Mundi 2012, 0259, 1-58.

61. Edmonds, R.L.; Eglitis, A. The role of the Douglas-fir beetle and wood borers in the decomposition of and nutrient release from Douglas-fir logs. Can. J. For. Res. 1989, 19, 853-859. [CrossRef]

62. Schowalter, T.D.; Zhang, Y.L.; Sabin, T.E. Decomposition and nutrient dynamics of oak (Quercus spp.) logs after five years of decomposition. Ecography 1998, 21, 3-10. [CrossRef]

63. Willett, T.R. Spiders and other arthropods as indicators in old-growth versus logged redwood stands. Restor. Ecol. 2001, 9, 410-420. [CrossRef]

64. Work, T.T. Edge Effects of Clearcut Harvesting on Ground Arthropod Species Composition and Predator Community Structure in Old-Growth Douglas-fir Forests. Ph.D. Thesis, Oregon State University, Corvallis, OR, USA, 2000.

65. Punttila, P.; Haila, Y.; Niemelä, J.; Pajunen, T. Ant communities in fragments of old-growth taiga and managed surroundings. Ann. Zool. Fennici 1994, 31, 131-144.

66. Berg, E.E.; Henry, J.D.; Fastie, C.L.; de Volder, A.D.; Matsuoka, S.M. Spruce beetle outbreaks on the Kenai Peninsula, Alaska, and Kluane National Park and Reserve, Yukon Territory: Relationship to summer temperatures and regional differences in disturbance regimes. For. Ecol. Manag. 2006, 227, 219-232. [CrossRef]

67. Mattson, W.J.; Haack, R.A. The role of drought in outbreaks of plant-eating insects. BioScience 1987, 37, 110-118. [CrossRef] 
68. Schowalter, T.D.; Hansen, E.M.; Molina, R.L.; Zhang, Y.L. Integrating the ecological roles of phytophagous insects, plant pathogens, and mycorrhizae in managed forests. In Creating a Forestry for the 21st Century: The Science of Ecosystem Management; Kohm, K.A., Franklin, J.F., Eds.; Island Press: Washington, DC, USA, 1997; pp. 171-189.

69. Kolb, T.E.; Dodds, K.A.; Clancy, K.M. Effect of western spruce budworm defoliation on the physiology and growth of potted Douglas-fir seedlings. For. Sci. 1999, 45, 280-291.

70. Alfaro, R.I.; Shepherd, R.F. Tree-ring growth of interior Douglas-fir after one year's defoliation by Douglas-fir tussock moth. For. Sci. 1991, 37, 959-964.

71. Trumble, J.T.; Kolodny-Hirsch, D.M.; Ting, I.P. Plant compensation for arthropod herbivory. Annu. Rev. Entomol. 1993, 38, 93-119. [CrossRef]

72. Ritchie, M.E.; Tilman, D.; Knops, J.M.H. Herbivore effects on plant and nitrogen dynamics in oak savanna. Ecology 1998, 79, 165-177. [CrossRef]

73. Breshears, D.D.; Cobb, N.S.; Rich, P.M.; Price, K.P.; Allen, C.D.; Balice, R.G.; Romme, W.H.; Kastens, J.H.; Floyd, M.L.; Belnap, J.; et al. Regional vegetation die-off in response to global-change-type drought. Proc. Natl. Acad. Sci. USA 2005, 102, 15144-15148. [CrossRef] [PubMed]

74. Orwig, D.A. Ecosystem to regional impacts of introduced pests and pathogens: Historical context, questions and issues. J. Biogeogr. 2002, 29, 1471-1474. [CrossRef]

75. Orwig, D.A.; Foster, D.R.; Mausel, D.L. Landscape patterns of hemlock decline in New England due to the introduced hemlock woolly adelgid. J. Biogeogr. 2002, 29, 1475-1487. [CrossRef]

76. Gandhi, K.J.K.; Herms, D.A. Direct and indirect effects of alien insect herbivores on ecological processes and interactions in forests of eastern North America. Biol. Invasions 2010, 12, 389-405. [CrossRef]

77. Adkins, J.K.; Rieske, L.K. Loss of a foundation forest species due to an exotic invader impacts terrestrial arthropod communities. For. Ecol. Manag. 2013, 295, 126-135. [CrossRef]

78. Gandhi, K.J.K.; Herms, D.A. North American arthropods at risk due to widespread Fraxinus mortality caused by the alien emerald ash borer. Biol. Invasions 2010, 12, 1839-1846. [CrossRef]

79. Frost, C.J.; Hunter, M.D. Recycling of nitrogen in herbivore feces: Plant recovery, herbivore assimilation, soil retention, and leaching losses. Oecologia 2007, 151, 42-53. [CrossRef] [PubMed]

80. Seastedt, T.R.; Crossley, D.A., Jr.; Hargrove, W.W. The effects of low-level consumption by canopy arthropods on the growth and nutrient dynamics of black locust and red maple trees in the southern Appalachians. Ecology 1983, 64, 1040-1048. [CrossRef]

81. Lindo, Z.; Winchester, N.N. Oribatid mite communities and foliar litter decomposition in canopy suspended soils and forest floor habitats of western red cedar forests. Soil Biol. Biochem. 2007, 39, 2957-2966. [CrossRef]

82. Mattson, W.J.; Addy, N.D. Phytophagous insects as regulators of forest primary production. Science 1975, 190,515-522. [CrossRef]

83. Wickman, B.E. Increased growth of white fir after a Douglas-fir tussock moth outbreak. J. For. 1980, 78, 31-33.

84. Goyer, R.A.; Wagner, M.R.; Schowalter, T.D. Current and proposed technologies for bark beetle management. J. For. 1998, 96, 29-33.

85. North, M.; Innes, J.; Zald, H. Comparison of thinning and prescribed fire restoration treatments to Sierran mixed-conifer historic conditions. Can. J. For. Res. 2007, 37, 331-342. [CrossRef]

(c) 2017 by the author. Licensee MDPI, Basel, Switzerland. This article is an open access article distributed under the terms and conditions of the Creative Commons Attribution (CC BY) license (http:/ / creativecommons.org/licenses/by/4.0/). 